\title{
Fatty acid flow to the duodenum of sheep fed diets supplemented with different types of fat ${ }^{*}$
}

\section{Szumacher-Strabel ${ }^{1}$, A. Potkański ${ }^{1}$, J. Kowalczyk ${ }^{2}$, A. Cieślak ${ }^{1,4}$, M. Czauderna ${ }^{2}$, G. Strzelecka ${ }^{1}$ and P. Jędroszkowiak ${ }^{3}$}

\author{
${ }^{1}$ Department of Animal Nutrition and Feed Management, \\ August Cieszkowski Agricultural University \\ Wotyńska 33, 60-637 Poznań, Poland \\ ${ }^{2}$ The Kielanowski Institute of Animal Physiology and Nutrition, \\ Polish Academy of Sciences \\ 05-110 Jabłonna, Poland \\ ${ }^{3}$ Berg + Schmidt Polska Sp. z o.o.
}

(Received 16 October 2003; accepted 4 April 2003)

\begin{abstract}
The effect of different types of fat supplementation on the flow of fatty acids to the duodenum was estimated on three milking sheep fitted with duodenal re-entrant cannula in a $3 \times 3$ Latin square design consisting of three experimental diets differing in the percentage of supplemental fat. The basic ration for the control group consisted of meadow hay and concentrate (60:40) and was supplemented for experimental groups with soyabean oil, linseed oil, tallow, Bergafat $t^{\circledR}$ preparation or fish oil at a level of 0 (control), 4 and 6\% in dry matter. Duodenal digesta was analyzed for fatty acids content. All of fats used, of both vegetable and animal origin, caused statistically significant changes in the passage of fatty acids to the duodenum. Soyabean oil added to sheep rations significantly decreased levels of particular saturated fatty acids and also the sum of saturated fatty acids. In response to supplementation with linseed oil, a source of polyunsaturated fatty acids, the level of MUFA and PUFA in the duodenum increased $(\mathrm{P}<0.05)$. Under the fish oil treatment we observed a decrease $(\mathrm{P}<0.01)$ in the levels of two saturated fatty acids, lauric and palmitic. Also most of the detected unsaturated fatty acids were affected by fat treatment. Under Bergafat ${ }^{\mathbb{B}}$ conditions, the passage of fatty acids to the duodenum did not point to any modifications in the fatty acids profile, except the concentration of oleic acid, which tended to increase $(\mathrm{P}<0.05)$. With the addition of tallow to sheep rations, the concentration of some fatty acids in duodenal digesta decreased significantly.
\end{abstract}

KEY WORDS: duodenum, fatty acids, fat, sheep

\footnotetext{
* Supported by the State Committee for Scientific Research, Grant No. 5 P06E 01119

${ }^{4} \mathrm{~A}$. Cieślak is a holder of a scholarship for young scientists from the Foundation for Polish Science (FNP)
} 


\section{INTRODUCTION}

Evidence from prospective cross-cultural, cohort, and interventional studies indicates that the risk of coronary heart disease in populations increases with increasing mean serum LDL-cholesterol levels, and the most important factor affecting serum LDL-cholesterol is the dietary fatty acid profile (Kromhout et al., 2002, cited by Aro, 2002). Much emphasis has been placed on the improvement of the fatty acid profile of products obtained from ruminants. It has been recognized for many years that in ruminants, the microbial processes in the rumen affect the composition of the fatty acids in dietary lipids before they are absorbed (Givens et al., 2001). The main end product of biohydrogenation is stearic acid, but according to Harfoot et al. (1973), when higher amounts of linoleic acid are available, biohydrogenation usually stops before the final step and various cis and trans isomers are formed. Hence, rumen-originating fatty acids flowing to the duodenum could be a marker of fatty-acid composition of products obtained from ruminants, e.g. milk and meat. Fatty acids that pass to the duodenum can be derived from three sources: endogenous sources, dietary lipids and de novo fatty acid synthesis by ruminal microorganisms (Christensen et al., 1998).

The objective of the performed experiments was to determine the effect of vegetable and animal fats on the passage of fatty acids to the duodenum in sheep.

\section{MATERIAL AND METHODS}

\section{Animals and diets}

The experiments were carried out in a $3 \times 3$ Latin square design on 3 milking ewes $(50 \pm 5 \mathrm{~kg})$ fitted with re-entrant duodenal cannula to determine the effect of fat source on fatty acids concentration in the duodenum. The basic ration for the control group consisted of meadow hay and concentrate (60:40), which was supplemented for the experimental groups with linseed oil (LSO), soyabean oil (SO), fish oil (FO), tallow (T) or Bergafat ${ }^{\mathbb{B}}$ preparation (B) at a level of 0 (control), 4 and $6 \%$ in dry matter of the diet. The concentrations of fatty acids in the fats and the energy value and protein content of the rations were described in our previously published paper (Szumacher-Strabel et al., 2002).

\section{Sampling and analysis}

The experiments consisted of three 16-day trials, 14 days for adaptation to the diet and the last two for duodenal digesta collection. Five-percent aliquots of total duodenal digesta entering the duodenum were taken and frozen until the fatty acids were analyzed. The fatty acid content in duodenal digesta was determined according to the procedures of Heinig et al. (1998), modified by Czauderna et al. (2001). 
Statistical analysis

All data were analyzed using SAS procedures (User's Guide, 1990).

\section{RESULTS}

All used fats, of either vegetable or animal origin, caused statistically significant changes in the passage of fatty acids to the duodenum. Soybean oil added to sheep rations (Table 1), a source of linoleic acid necessary for cis and trans forms

TABLE 1

Fatty acids concentration in duodenal digesta of sheep fed diets supplemented with soyabean oil, \%

\begin{tabular}{|c|c|c|c|c|c|c|}
\hline & \multicolumn{3}{|c|}{ Fat added to basal diets, $\%$} & \multirow{2}{*}{ Mean } & \multirow{2}{*}{ SD } & \multirow{2}{*}{$\mathrm{P}>\mathrm{F}$} \\
\hline & 0 & 4 & 6 & & & \\
\hline C8:0 & $6.07^{\mathrm{A}}$ & $1.22^{\mathrm{B}}$ & $0.52^{\mathrm{B}}$ & 2.60 & 3.102 & 0.0314 \\
\hline C10:0 & $0.72^{\mathrm{a}}$ & $0.24^{\mathrm{b}}$ & $0.10^{\mathrm{b}}$ & 0.35 & 0.298 & 0.0032 \\
\hline $\mathrm{C} 12: 0$ & $1.60^{\mathrm{A}}$ & $0.83^{\mathrm{B}}$ & $0.50^{\mathrm{B}}$ & 0.98 & 0.581 & 0.0286 \\
\hline $\mathrm{C} 14: 0$ & $2.11^{\mathrm{A}}$ & $0.69^{\mathrm{B}}$ & $0.48^{\mathrm{B}}$ & 1.09 & 0.796 & 0.0200 \\
\hline $\mathrm{C} 16: 0$ & 12.83 & 7.84 & 7.48 & 9.38 & 3.909 & 0.2183 \\
\hline C18:0 & $37.79^{\mathrm{A}}$ & $17.85^{\mathrm{B}}$ & $25.39^{\mathrm{AB}}$ & 27.01 & 11.943 & 0.0229 \\
\hline C18:1 cis-9 & $5.47^{\mathrm{A}}$ & $2.71^{\mathrm{AB}}$ & $2.25^{\mathrm{B}}$ & 3.48 & 1.779 & 0.0404 \\
\hline C18:1 cis-6 & $19.97^{\mathrm{a}}$ & $63.49^{\mathrm{b}}$ & $59.75^{\mathrm{b}}$ & 47.74 & 22.151 & 0.0022 \\
\hline C18:1 trans-9 & 0.84 & 0.38 & 0.19 & 0.47 & 0.825 & 0.6874 \\
\hline C18:1 trans-7 & 0.33 & 0.16 & 0.09 & 0.19 & 0.326 & 0.7170 \\
\hline C18:1 trans- 6 & 0.71 & 0.48 & 0.29 & 0.49 & 0.705 & 0.8129 \\
\hline C18:2 cis- 9,12 & 7.44 & 2.77 & 2.16 & 4.12 & 2.646 & 0.0042 \\
\hline C18:3 cis- $9,12,15$ & $2.90^{\mathrm{a}}$ & $0.83^{\mathrm{b}}$ & $0.47^{\mathrm{b}}$ & 1.40 & 1.182 & 0.0025 \\
\hline C18:3 cis- $6,9,12$ & 0.25 & 0.22 & 0.18 & 0.22 & 0.225 & 0.9540 \\
\hline C18:3 trans- $9,12,15$ & $0.95^{\mathrm{a}}$ & $0.27^{\mathrm{b}}$ & $0.13^{\mathrm{b}}$ & 0.45 & 0.388 & 0.0029 \\
\hline SFA $^{1}$ & $61.12^{\mathrm{a}}$ & $28.67^{b}$ & $34.48^{b}$ & 41.42 & 17.053 & 0.0036 \\
\hline MUFA $^{2}$ & $27.33^{\mathrm{a}}$ & $67.22^{\mathrm{b}}$ & $62.57^{\mathrm{b}}$ & 52.37 & 20.443 & 0.0016 \\
\hline PUFA $^{3}$ & $11.55^{\mathrm{a}}$ & $4.12^{\mathrm{b}}$ & $2.95^{\mathrm{b}}$ & 6.21 & 4.182 & 0.0030 \\
\hline PUFA-3 & $3.85^{\mathrm{a}}$ & $1.11^{\mathrm{b}}$ & $0.61^{\mathrm{b}}$ & 1.85 & 1.558 & 0.0020 \\
\hline PUFA-6 & $7.69^{\mathrm{a}}$ & $2.99^{\mathrm{b}}$ & $2.33^{\mathrm{b}}$ & 4.34 & 2.717 & 0.0072 \\
\hline MUFA+PUFA & $38.87^{\mathrm{b}}$ & $71.34^{\mathrm{a}}$ & $65.52^{\mathrm{a}}$ & 58.58 & 17.054 & 0.0036 \\
\hline PUFA-6:PUFA-3 & $1.96: 1^{\mathrm{A}}$ & $2.78: 1^{\mathrm{AB}}$ & $3.57: 1^{\mathrm{B}}$ & $2.56: 1$ & 1.156 & 0.0233 \\
\hline
\end{tabular}

means with the same letter are not significantly different. ${ }^{\mathrm{A}, \mathrm{B}} \mathrm{P}<0.05$, ${ }^{\mathrm{a}, \mathrm{b}} \mathrm{P}<0.01$

${ }^{1}$ saturated fatty acids

${ }^{2}$ monounsaturated fatty acids

${ }^{3}$ polyunsaturated fatty acids 
produced during biohydrogenation in the rumen, significantly decreased the level of particular saturated fatty acids and also the sum of saturated fatty acids when 4 and $6 \%$ of fat were added. The sum of saturated fatty acids ranged from $61.12 \%$ in the control group, to 28.67 and $34.48 \%$ in experimental groups, respectively. A statistically significant increase $(\mathrm{P}<0.01)$ in MUFA content was observed, whereas PUFA decreased $(\mathrm{P}<0.01)$ significantly. Both the PUFA-3 and PUFA-6 levels in the duodenum were reduced by fat addition. The PUFA-3 level was reduced $(\mathrm{P}<0.01)$ from $3.85 \%$ in the control group, to 1.11 and $0.61 \%$, respectively, in the experimental groups. There was also a significant effect of fat addition on the PUFA-6 level, which decreased from $7.69 \%$ in the control group to 2.99 and $2.33 \%$, respectively, in groups receiving 4 and $6 \%$ of soyabean oil in dry matter. The ratio of $n-6: n-3$ PUFA was also influenced $(\mathrm{P}<0.05)$ by fat supplementation and ranged from $1.96: 1$ in the control group to $2.78: 1$ and $3.57: 1$, respectively in the experimental groups.

TABLE 2

Fatty acids concentration in duodenal digesta of sheep fed diets supplemented with linseed oil, \%

\begin{tabular}{|c|c|c|c|c|c|c|}
\hline & \multicolumn{3}{|c|}{ Fat added to basal diets, $\%$} & \multirow{2}{*}{ Mean } & \multirow{2}{*}{ SD } & \multirow{2}{*}{$\mathrm{P}>\mathrm{F}$} \\
\hline & 0 & 4 & 6 & & & \\
\hline $\bar{C} 8: 0$ & 2.44 & 0.93 & 1.65 & 1.67 & 1.307 & 0.3574 \\
\hline $\mathrm{C} 10: 0$ & 0.62 & 0.33 & 1.48 & 0.81 & 1.341 & 0.6057 \\
\hline $\mathrm{C} 12: 0$ & 1.03 & 0.54 & 0.46 & 0.68 & 0.372 & 0.0467 \\
\hline $\mathrm{C} 14: 0$ & 1.11 & 0.45 & 1.07 & 0.88 & 0.804 & 0.5603 \\
\hline $\mathrm{C} 16: 0$ & 12.38 & 6.00 & 5.96 & 8.11 & 3.905 & 0.0824 \\
\hline C18:0 & $24.79^{\mathrm{A}}$ & $16.20^{\mathrm{AB}}$ & $6.09^{\mathrm{B}}$ & 15.70 & 8.791 & 0.0178 \\
\hline C18:1 cis-9 & 4.82 & 2.31 & 6.00 & 4.38 & 3.024 & 0.3571 \\
\hline C18:1 cis-6 & 40.99 & 69.80 & 66.66 & 59.15 & 18.391 & 0.1439 \\
\hline C18:1 trans- 9 & 1.30 & 0.30 & 0.90 & 0.83 & 0.830 & 0.3520 \\
\hline C18:1 trans-7 & 0.47 & 0.09 & 0.34 & 0.30 & 0.305 & 0.2344 \\
\hline C18:1 trans- 6 & 1.16 & 0.35 & 1.07 & 0.86 & 0.675 & 0.2997 \\
\hline C18:2 cis- 9,12 & 6.28 & 1.43 & 5.91 & 4.54 & 4.069 & 0.3191 \\
\hline C18:3 cis- $9,12,15$ & 1.50 & 0.87 & 1.15 & 1.17 & 0.757 & 0.6895 \\
\hline C18:3 cis- $6,9,12$ & 0.52 & 0.18 & 0.78 & 0.49 & 0.324 & 0.0728 \\
\hline C18:3 trans- $9,12,15$ & 0.52 & 0.19 & 0.46 & 0.39 & 0.359 & 0.5334 \\
\hline $\mathrm{SFA}^{1}$ & $42.38^{\mathrm{A}}$ & $24.45^{\mathrm{AB}}$ & $16.71^{\mathrm{B}}$ & 27.85 & 12.596 & 0.0265 \\
\hline MUFA $^{2}$ & 48.74 & 72.85 & 74.98 & 65.52 & 15.377 & 0.0819 \\
\hline PUFA $^{3}$ & 8.88 & 2.70 & 8.31 & 6.63 & 5.285 & 0.3363 \\
\hline PUFA-3 & 2.02 & 1.06 & 1.60 & 1.56 & 1.097 & 0.6442 \\
\hline PUFA-6 & 6.80 & 1.61 & 6.69 & 5.03 & 4.260 & 0.2727 \\
\hline MUFA+PUFA & $57.56^{\mathrm{B}}$ & $75.53^{\mathrm{AB}}$ & $83.27^{\mathrm{A}}$ & 72.12 & 12.612 & 0.0264 \\
\hline PUFA-6:PUFA-3 & $3.57: 1$ & $1.52: 1$ & $4.35: 1$ & $2.56: 1$ & 1.133 & 0.3720 \\
\hline
\end{tabular}

means with the same letter are not significantly different. ${ }^{\mathrm{A}, \mathrm{B}} \mathrm{P}<0.05,{ }^{\mathrm{a}, \mathrm{b}} \mathrm{P}<0.01$

${ }^{1}$ saturated fatty acids

${ }^{2}$ monounsaturated fatty acids

${ }^{3}$ polyunsaturated fatty acids 
TABLE 3

Fatty acids concentration in duodenal digesta of sheep fed diets supplemented with fish oil, \%

\begin{tabular}{|c|c|c|c|c|c|c|}
\hline & \multicolumn{3}{|c|}{ Fat added to basal diets, $\%$} & \multirow{2}{*}{ Mean } & \multirow{2}{*}{ SD } & \multirow{2}{*}{$\mathrm{P}>\mathrm{F}$} \\
\hline & 0 & 4 & 6 & & & \\
\hline $\mathrm{C} 8: 0$ & 2.19 & 0.63 & 0.47 & 0.96 & 0.818 & 0.0591 \\
\hline $\mathrm{C} 10: 0$ & 0.60 & 0.11 & 0.06 & 0.21 & 0.272 & 0.0850 \\
\hline $\mathrm{C} 12: 0$ & 1.05 & 0.57 & 0.32 & 0.59 & 0.395 & 0.2877 \\
\hline C14:0 & $1.62^{\mathrm{a}}$ & $0.54^{\mathrm{b}}$ & $0.33^{\mathrm{b}}$ & 0.73 & 0.562 & 0.0018 \\
\hline $\mathrm{C} 16: 0$ & $15.84^{\mathrm{A}}$ & $8.55^{\mathrm{B}}$ & $7.54^{\mathrm{B}}$ & 9.99 & 3.733 & 0.0112 \\
\hline C18:0 & 29.48 & 18.64 & 24.33 & 23.48 & 12.858 & 0.8300 \\
\hline C18:1 cis-9 & $6.89^{\mathrm{a}}$ & $2.85^{\mathrm{b}}$ & $1.56^{\mathrm{b}}$ & 3.38 & 2.296 & 0.0079 \\
\hline C18:1 cis-6 & 28.88 & 63.56 & 62.20 & 54.38 & 19.483 & 0.1145 \\
\hline C18:1 trans-9 & 0.78 & 0.21 & 0.26 & 0.37 & 0.500 & 0.4854 \\
\hline C18:1 trans-7 & 0.33 & 0.08 & 0.12 & 0.16 & 0.207 & 0.5177 \\
\hline C18:1 trans-6 & $1.33^{\mathrm{A}}$ & $0.31^{\mathrm{B}}$ & $0.41^{\mathrm{C}}$ & 0.60 & 0.515 & 0.0428 \\
\hline C18:2 cis- 9,12 & $7.91^{\mathrm{A}}$ & $3.25^{\mathrm{B}}$ & $1.46^{\mathrm{B}}$ & 3.74 & 2.805 & 0.0127 \\
\hline C18:3 cis- $9,12,15$ & $1.83^{\mathrm{a}}$ & $0.37^{\mathrm{b}}$ & $0.34^{\mathrm{b}}$ & 0.72 & 0.734 & 0.0085 \\
\hline C18:3 cis- $6,9,12$ & 0.49 & 0.21 & 0.48 & 0.38 & 0.311 & 0.1839 \\
\hline C18:3 trans- $9,12,15$ & $0.72^{\mathrm{a}}$ & $0.13^{\mathrm{b}}$ & $0.12^{\mathrm{b}}$ & 0.27 & 0.280 & 0.0069 \\
\hline SFA $^{1}$ & 50.77 & 29.03 & 33.05 & 35.97 & 15.259 & 0.4740 \\
\hline MUFA $^{2}$ & 38.19 & 67.01 & 64.55 & 58.88 & 17.364 & 0.2289 \\
\hline PUFA $^{3}$ & $11.04^{\mathrm{a}}$ & $3.96^{\mathrm{b}}$ & $2.41^{\mathrm{b}}$ & 5.15 & 3.753 & 0.0044 \\
\hline PUFA-3 & $2.54^{\mathrm{A}}$ & $0.74^{\mathrm{B}}$ & $0.46^{\mathrm{B}}$ & 1.14 & 0.994 & 0.0218 \\
\hline PUFA-6 & $8.39^{\mathrm{a}}$ & $2.75^{\mathrm{b}}$ & $1.94^{\mathrm{b}}$ & 4.02 & 3.028 & 0.0077 \\
\hline MUFA+PUFA & 64.48 & 75.68 & 74.49 & 73.22 & 13.865 & 0.9949 \\
\hline PUFA-6:PUFA-3 & $3.33: 1$ & $3.70: 1$ & $4.00: 1$ & $3.70: 1$ & 0.052 & 0.5664 \\
\hline
\end{tabular}

means with the same letter are not significantly different. ${ }^{\mathrm{A}, \mathrm{B}} \mathrm{P}<0.05$, , ${ }^{\mathrm{a}, \mathrm{b}} \mathrm{P}<0.01$

${ }^{1}$ saturated fatty acids

${ }^{2}$ monounsaturated fatty acids

${ }^{3}$ polyunsaturated fatty acids

A less detrimental effect of fat in the sheep ration was observed when linseed oil was added (Table 2$)$. We observed a significant $(\mathrm{P}<0.05)$ decrease in the stearic acid level when this oil was supplemented. The level of stearic acid ranged from $24.79 \%$ in the control group to 16.20 and $6.09 \%$ when 4 and $6 \%$ of linseed oil was added to the ration. As a consequence of the decline in stearic acid, we noticed a significant $(\mathrm{P}<0.05)$ decrease in the level of total saturated fatty acids. In response to linseed oil supplementation, a source of polyunsaturated fatty acids, the level of MUFA and PUFA in the duodenum increased $(\mathrm{P}<0.05)$.

Under the fish oil treatment we observed a decrease $(\mathrm{P}<0.01)$ in two saturated fatty acid levels: lauric and palmitic (Table 3). Also most of the detected unsaturated fatty acids were affected by fat treatment. We noticed a decreased level of monounsaturated fatty acids, oleic $(\mathrm{P}<0.01)$ and petroselaidic $(\mathrm{P}<0.05)$, and polyunsaturated fatty acids: ricinoleic, linolenic and linolenelaidic. Fat diets 
reduced the flow of the sum of polyunsaturated fatty acids, PUFA-3 $(\mathrm{P}<0.05)$ and PUFA-6 $(\mathrm{P}<0.01)$ to the duodenum. The PUFA n-3 concentration decreased from $2.54 \%$ in the control group, to 0.74 and $0.46 \%$ in the experimental groups. The rations supplemented with 4 and $6 \%$ of fish oil decreased the flow of PUFA6 to the duodenum from $8.39 \%$ in the control group, to 2.75 and $1.94 \%$ in the experimental groups, respectively. We observed a high, but not statistically significant increase of C18:1 cis 6 and as a consequence of the increase of MUFA and also the sum of MUFA and PUFA levels.

Under Bergafat ${ }^{\mathbb{B}}$ conditions, the passage of fatty acids to the duodenum did not point to any modifications in the fatty acid profile, except the concentration of oleic acid, which tended to increase $(\mathrm{P}<0.05)$. The oleic acid level increased to 2.48 and $3.08 \%$ when compared with $0.91 \%$ in control group (Table 4 ).

TABLE 4

Fatty acids concentration in duodenal digesta of sheep fed diets supplemented with Bergafat ${ }^{\mathbb{B}}, \%$

\begin{tabular}{|c|c|c|c|c|c|c|}
\hline & \multicolumn{3}{|c|}{ Fat added to basal diets, $\%$} & \multirow{2}{*}{ Mean } & \multirow{2}{*}{ SD } & \multirow{2}{*}{$\mathrm{P}>\mathrm{F}$} \\
\hline & 0 & 4 & 6 & & & \\
\hline $\mathrm{C} 8: 0$ & 0.87 & 0.56 & 0.41 & 0.65 & 0.388 & 0.6830 \\
\hline $\mathrm{C} 10: 0$ & 0.15 & 0.11 & 0.10 & 0.12 & 0.068 & 0.6489 \\
\hline $\mathrm{C} 12: 0$ & 2.71 & 1.30 & 0.21 & 1.64 & 1.894 & 0.5576 \\
\hline $\mathrm{C} 14: 0$ & 0.93 & 0.50 & 0.36 & 0.64 & 0.515 & 0.7650 \\
\hline $\mathrm{C} 16: 0$ & 4.78 & 6.32 & 7.96 & 6.03 & 3.354 & 0.7943 \\
\hline $\mathrm{C} 18: 0$ & 30.17 & 29.81 & 17.42 & 27.48 & 6.479 & 0.5174 \\
\hline C18:1 cis-9 & $0.91^{\mathrm{A}}$ & $2.48^{\mathrm{B}}$ & $3.08^{\mathrm{C}}$ & 1.97 & 1.090 & 0.0570 \\
\hline C18:1 cis-6 & 52.63 & 54.89 & 65.29 & 56.06 & 5.420 & 0.2469 \\
\hline C18:1 trans- 9 & 0.43 & 0.45 & 0.45 & 0.44 & 0.170 & 0.9270 \\
\hline $\mathrm{C} 18: 1$ trans- 7 & 0.22 & 0.14 & 0.16 & 0.18 & 0.089 & 0.4785 \\
\hline C18:1 trans- 6 & 0.58 & 0.47 & 0.46 & 0.51 & 0.101 & 0.7857 \\
\hline C18:2 cis- 9,12 & 3.73 & 1.96 & 3.00 & 2.88 & 1.790 & 0.8143 \\
\hline C18:3 cis-9,12,15 & 0.77 & 0.54 & 0.56 & 0.63 & 0.273 & 0.7867 \\
\hline C18:3 cis- $6,9,12$ & 0.82 & 0.29 & 0.26 & 0.50 & 0.577 & 0.7275 \\
\hline C18:3 trans- $9,12,15$ & 0.31 & 0.20 & 0.23 & 0.25 & 0.133 & 0.8508 \\
\hline $\mathrm{SFA}^{1}$ & 39.61 & 38.60 & 26.46 & 36.57 & 6.667 & 0.5106 \\
\hline MUFA $^{2}$ & 54.77 & 58.41 & 69.44 & 59.16 & 6.214 & 0.2595 \\
\hline PUFA $^{3}$ & 5.64 & 2.99 & 4.08 & 4.27 & 2.722 & 0.7999 \\
\hline PUFA-3 & 1.07 & 0.74 & 0.79 & 0.88 & 0.405 & 0.8113 \\
\hline PUFA-6 & 4.55 & 2.25 & 3.26 & 3.37 & 2.320 & 0.8003 \\
\hline MUFA+PUFA & 60.39 & 61.40 & 73.49 & 63.41 & 6.650 & 0.5120 \\
\hline PUFA-6:PUFA-3 & $3.70: 1$ & $2.94: 1$ & $4.17: 1$ & $3.45: 1$ & 0.083 & 0.8356 \\
\hline
\end{tabular}

means with the same letter are not significantly different. ${ }^{\text {A.B }} \mathrm{P}<0.05$, ${ }^{\text {a.b }} \mathrm{P}<0.01$

${ }^{1}$ saturated fatty acids

${ }^{2}$ monounsaturated fatty acids

${ }^{3}$ polyunsaturated fatty acids 
TABLE 5

Fatty acids concentration in duodenal digesta of sheep fed diets supplemented with tallow. \%

\begin{tabular}{|c|c|c|c|c|c|c|}
\hline & \multicolumn{3}{|c|}{ Fat added to basal diets, $\%$} & \multirow{2}{*}{ Mean } & \multirow{2}{*}{ SD } & \multirow{2}{*}{$\mathrm{P}>\mathrm{F}$} \\
\hline & 0 & 4 & 6 & & & \\
\hline C8:0 & 3.81 & 2.04 & 0.57 & 2.38 & 2.008 & 0.1609 \\
\hline $\mathrm{C} 10: 0$ & 1.19 & 0.22 & 0.12 & 0.60 & 0.879 & 0.3486 \\
\hline $\mathrm{C} 12: 0$ & $1.41^{\mathrm{A}}$ & $0.47^{\mathrm{AB}}$ & $0.34^{\mathrm{B}}$ & 0.83 & 0.605 & 0.0365 \\
\hline $\mathrm{C} 14: 0$ & 4.04 & 1.53 & 1.615 & 2.63 & 2.313 & 0.4060 \\
\hline $\mathrm{C} 16: 0$ & 15.02 & 20.88 & 20.09 & 18.14 & 5.296 & 0.7676 \\
\hline $\mathrm{C} 18: 0$ & 28.66 & 41.72 & 34.20 & 33.97 & 9.351 & 0.6549 \\
\hline C18:1 cis-9 & 6.45 & 4.59 & 5.41 & 5.621 & 1.173 & 0.4162 \\
\hline C18:1 cis- 6 & 26.52 & 21.48 & 32.09 & 26.67 & 13.234 & 0.8613 \\
\hline C18:1 trans-9 & 2.16 & 0.76 & 0.6 & 1.423 & 0.918 & 0.1345 \\
\hline C18:1 trans-7 & 0.84 & 0.21 & 0.10 & 0.52 & 0.445 & 0.0746 \\
\hline C18:1 trans-6 & 1.69 & 1.19 & 1.35 & 1.45 & 0.266 & 0.0951 \\
\hline C18:2 cis-9.12 & 1.31 & 0.55 & 0.50 & 0.79 & 0.437 & 0.3094 \\
\hline C18:3 cis-9.12.15 & $1.06^{\mathrm{A}}$ & $0.43^{\mathrm{B}}$ & $0.21^{\mathrm{B}}$ & 0.64 & 0.422 & 0.0263 \\
\hline $\mathrm{C} 18: 3$ cis- 6.9 .12 & 8.06 & 3.83 & 2.61 & 4.835 & 2.675 & 0.1621 \\
\hline C18:3 trans- 9.12 .15 & $2.68^{\mathrm{A}}$ & $1.15^{\mathrm{AB}}$ & $0.52^{\mathrm{B}}$ & 1.63 & 1.049 & 0.0288 \\
\hline $\mathrm{SFA}^{1}$ & 54.14 & 66.87 & 56.95 & 58.58 & 13.927 & 0.8750 \\
\hline MUFA $^{2}$ & 41.46 & 47.9 & 39.55 & 44.68 & 4.554 & 0.1436 \\
\hline PUFA $^{3}$ & 13.16 & 5.97 & 3.85 & 7.66 & 4.497 & 0.2632 \\
\hline PUFA-3 & $3.75^{\mathrm{A}}$ & $1.58^{\mathrm{B}}$ & $0.73^{\mathrm{B}}$ & 2.27 & 1.464 & 0.0238 \\
\hline PUFA-6 & 9.37 & 4.38 & 3.11 & 5.62 & 3.054 & 0.2963 \\
\hline MUFA+PUFA & 53.94 & 52.4 & 43.40 & 53.17 & 1.089 & 0.2464 \\
\hline PUFA-6:PUFA-3 & $2.50: 1^{\mathrm{A}}$ & $2.78: 1^{\mathrm{A}}$ & $4.35: 1^{\mathrm{B}}$ & $3.03: 1$ & 0.08 & 0.0364 \\
\hline
\end{tabular}

means with the same letter are not significantly different. ${ }^{\text {A.B }} \mathrm{P}<0.05$, ${ }^{\text {a.b }} \mathrm{P}<0.01$

${ }^{1}$ saturated fatty acids

${ }^{2}$ monounsaturated fatty acids

${ }^{3}$ polyunsaturated fatty acids

When tallow was added to the sheep rations, the concentration of some duodenal fatty acids decreased significantly (Table 5). Most of the changes were connected with the level of polyunsaturated fatty acids, which were significantly decreased when diets were supplemented with additional fat. The level of linolenic acid (cis $9,12,15)$ decreased $(\mathrm{P}<0.05)$ from $1.06 \%$ in the control group to 0.43 and $0.21 \%$, respectively, in experimental groups. Also linolenelaidic acid (trans 9, 12, 15) was decreased when tallow was added. The concentration of this fatty acid ranged from $2.68 \%$, to 1.11 and $0.52 \%$ when the diets, contained 4 and $6 \%$ of tallow in dry matter. We also observed a significant decrease in the PUFA-3 level $(\mathrm{P}<0.05)$ and in the PUFA-6 : PUFA-3 ratio $(\mathrm{P}<0.05)$, from $2.50: 1$ in the control group to 2.78:1 and 4.35:1, respectively, in the experimental groups. On the other hand, under this treatment a slight but statistically insignificant increase in palmitic and stearic acid levels was observed. Furthermore, the total saturated fatty acid abundance (SFA) increased when tallow was added to the sheep ration. 


\section{DISCUSSION}

Over the past 40 years, awareness of the association of dietary fat with cardiovascular disease has become entrenched in the marketplace and in the attitude of consumers towards their food; a huge industry has developed to provide 'low-fat', 'fat-free' or functional food products for a 'healthy' lifestyle (Reynolds and Dewhurst, 2002). Generally, consumers should follow recommendations and change their total dietary intake of fat, the proportion of their dietary fat that is saturated, the ratio of n-6:n-3 PUFA in their diets, and intake of trans fatty acids (Gurr, 1999). To meet consumer demand, it is necessary to considerably change the composition of ruminant meat and milk, and to achieve this, i.e. to modify the quantity and composition of fatty acids in animal products, the fatty acid profile in diets used in animal nutrition should be altered. Ruminant body fat usually contains a higher proportion of saturated fatty acids than diets fed; these saturated fatty acids are formed in the rumen during biohydrogenation. Attempting to enhance the nutritional quality of ruminant diets with unsaturated fats necessitates optimal escape of the fatty acids from ruminal biohydrogenation (Kucuk et al., 2001). Dietary fat can modify this process, resulting in higher proportions of unsaturated fatty acids flowing to the duodenum and higher unsaturated fatty acid contents in ruminant products. The fatty acid profile of fats reaching the duodenum is usually used as a marker of fatty-acid composition in obtained products. The results of our experiments demonstrated that vegetable fats, especially soyabean oil, and fish oil added to sheep rations caused a decrease in the duodenal passage of most saturated fatty acids. Diets supplemented with tallow, which is mostly a source of saturated fatty acids, significantly decreased the level of C12:0 and increased the level of C16:0 and C18:0 saturated fatty acids passing into the duodenum, but the differences were not statistically significant. Bergafat ${ }^{\mathbb{B}}$ had no influence on the level of saturated fatty acids reaching the duodenum. In our experiments, fats added to basal diets generally increased the flow of monounsaturated fatty acids to the duodenum. The addition of soyabean oil resulted in increased flow of petroselinic acid (cis 6 C18: 1) and a higher total MUFA level. Linseed oil increased the level of total MUFA and PUFA. Fish oil increased the level of some monounsaturated fatty acid (e.g. C18:1 cis-6) but the differences were not statistically significant, whereas when Bergafat ${ }^{\circledR}$ was added to the ration, passage of oleic acid increased. None of the used fats increased the level of particular polyunsaturated fatty acids or total PUFA in duodenal digesta. Unexpectedly, we did not observe benefits of increased consumption of fish oil (a source of n-3 fatty acids) or other vegetable oils rich in n-3 PUFA. It is not known with certainty what the optimum or desirable dietary ratio of n-6:n-3 PUFA is for man. However, current evidence suggests that a value in range from 5:1 to $1: 1$ is probably reasonable, whereas a value in the region of $50: 1$ is undoubtedly excessive (Sargent, 1995; Cowing and Saker, 2001; Givens et al., 2001). Though 
we noticed statistically significant differences only when soyabean oil and tallow were added to the rations, we realize that regardless of the type of fat added to sheep rations in our experiments, the ratio of n-6:n-3 was in the proper range and, as a consequence, could improve the fatty-acid composition of milk and meat. Our previous experiments demonstrated that rapeseed oil, hydrogenated rapeseed oil and linseed oil added to the diet caused a decrease in saturated but increase of total unsaturated, mostly monounsaturated fatty acids, in duodenal digesta of sheep (Potkański et al., 2001). Data obtained by Wagner et al. (1998) demonstrate that long-chain fatty acids reaching the duodenum seem to enter directly into milk fat, which confirms the thesis that the fatty-acid composition of duodenal digesta is a good marker of the fatty-acid composition of the obtained products. To establish the effect of fat added to sheep rations on biohydrogenation and hence on fatty acid profile reaching the duodenum, further study is required.

\section{REFERENCES}

Aro A., 2002. Human health effects of ruminant fats. Proceedings of XIV International Silage Conference. Auchincruive, Scotland (UK), pp. 2-5

Christensen R.A., Clark J.H., Drackley J.K., Blum S.A., 1998. Fatty acid flow to the duodenum and in milk from cows fed diets that contained fat and nicotinic acid. J. Dairy Sci. 81, 1078-1088

Cowing B.E., Saker K.F., 2001. Polyunsaturated fatty acids and epidermal growth factor receptor/ nitrogen activated protein kinase signaling in mammary cancer. J. Nutr. 131, 1125-1128

Czauderna M., Kowalczyk J., Chojecki G., 2001. Separation of some mono-, di- and triunsaturated fatty acids containing eighteen carbon atoms by HPLC and photodiode array detection. J. Chromatogr. B, 760, 165-178

Givens D.I., Cottrill B.R., Davies M., Lee P.A., Mansbridge R.J., Moss A.R., 2001. Sources of n-3 polyunsaturated fatty acids additional to fish oil for livestock diets - a review. Nutr. Abstr. Rev. $71,53 \mathrm{R}-83 \mathrm{R}$

Gurr M.I., 1999. Lipids in Nutrition and Health. A Reappraisal. The Oily Press, Bridgewater, UK

Harfoot C.G., Noble R.C., Moore J.H., 1973. Food particles as a site for biohydrogenation of unsaturated fatty acids in the rumen. Biochem. J. 132, 829-832

Heinig K., Hissner F., Martin S., Vogt C., 1998. Separation of saturated and unsaturated fatty acids by capillary electrophoresis and HPLC. Amer. Lab., May, 24-29

Kromhout D., Menotti A., Bloemberg B., 1995. Dietary saturated and trans fatty acids cholesterol and 25-year mortality from coronary heart disease. Preventive Med. 24, 308-315

Kucuk O., Hess B.W., Ludden P.A., Rule D.C., 2001. Effect of forage:concentrate ratio on ruminal digestion and duodenal flow of fatty acids in ewes. J. Anim. Sci. 79, 2233-2240

Potkański A., Szumacher-Strabel M., Kowalczyk J., Cieślak A., Czauderna M., 2001. A note on the effect of different amounts and types of fat on the fatty acid composition of duodenal digesta in sheep. J. Anim. Feed Sci. 10, 627-632

Reynolds C.K., Dewhurst R.J., 2002. The manipulation of ruminant products to improve their health properties. Proceedings of XIV International Silage Conference.Auchincruive, Scotland (UK), pp. 7-15 
Sargent J.R., Henderson R.J., 1995. Marine (n-3) polyunsaturated fatty acids. In: R.J. Hamilton (Editor). Developments in Oils and Fats. Blackie Academic and Professional, Glasgow (UK), pp. 32-65

SAS, 1990. SAS/STAT Users Guide (Release 6.03). SAS Institute Inc., Cary, NC, USA

Szumacher-Strabel M., Potkański A., Kowalczyk J., Cieślak A., Czauderna M., Gubała A., Jędroszkowiak P., 2002. Influence of supplemental fat on rumen volatile fatty acid profile, ammonia and $\mathrm{pH}$ level in sheep fed a standard diet. J. Anim. Feed Sci. 11, 577-587

Wagner K., Aulrich K., Lebzien P., Flachowsky., 1998. Research note: Effect of duodenal-infused unsaturated fatty acids on dairy milk composition. Arch. Anim. Nutr. 51, 349-354

\section{STRESZCZENIE}

\section{Dopływ kwasów tluszczowych do dwunastnicy owiec żywionych dawką z dodatkiem różnych źródel tluszczu}

Celem przeprowadzonych doświadczeń było określenie wpływu rodzaju dodanego tłuszczu do dawek składających się z siana i mieszanki treściwej (60:40\%) na skład i wzajemne proporcje kwasów tłuszczowych dopływających do dwunastnicy. Doświadczenia przeprowadzono na trzech owcach mlecznych z trwałymi kaniulami dwunastnicy, w układzie kwadratu łacińskiego 3 x 3 . Do dawki kontrolnej dodano thuszcze różniące się poziomem długołańcuchowych kwasów tłuszczowych, pochodzenia roślinnego i zwierzęcego: olej sojowy, olej lniany, łój, Bergafat ${ }^{\mathbb{B}}$ lub olej rybny w ilości 0 (grupa kontrolna), 4 lub 6\% suchej masy paszy. W pobranych próbach dwunastnicy oznaczono poziom długołańcuchowych kwasów thuszczowych. Wszystkie zastosowane thuszcze spowodowały zmiany w ilości i wzajemnych proporcjach kwasów tłuszczowych w dwunastnicy owiec. Dodatek oleju sojowego obniżył statystycznie istotnie poziom poszczególnych nasyconych kwasów tłuszczowych, a także sumę nasyconych kwasów tłuszczowych dopływających do dwunastnicy. Olej lniany dodany do dawki spowodował wzrost poziomu MUFA i PUFA $(\mathrm{P} \leq 0,05)$. Dodatek oleju rybnego do dawek spowodował spadek poziomu kwasu laurynowego i palmitynowego. Zarówno Bergafat ${ }^{\mathbb{R}}$, jak i łój dodane do dawek dla owiec nie miały wpływu na poziom kwasów tłuszczowych, z wyjątkiem kwasu oleinowego. Dodatek Bergafatu ${ }^{\circledR}$ zwiększył poziom kwasu oleinowego w dwunastnicy. 